\title{
Corrosion of Mullite by Molten Salts
}

\author{
Nathan S. Jacobson ${ }^{*}$ and Kang N. Lee ${ }^{* * *}$ \\ NASA Lewis Research Center, Cleveland, Ohio 44135 \\ Tetsuo Yoshio* \\ Okayama University, Okayama, Japan
}

The interaction of molten salts of different $\mathrm{Na}_{2} \mathrm{O}$ activities and mullite is examined with furnace and burner tests. The more-acidic molten salts form small amounts of $\mathrm{Al}_{2} \mathrm{O}_{3}$; the more-basic molten salts form various $\mathrm{Na}_{2} \mathrm{O}-\mathrm{Al}_{2} \mathrm{O}_{3}-\mathrm{SiO}_{2}$ compounds. The results are interpreted using the $\mathrm{Na}_{2} \mathrm{O}-$ $\mathrm{Al}_{2} \mathrm{O}_{3}-\mathrm{SiO}_{2}$ ternary phase diagram, and some possible diffusion paths are discussed. The generally higher melting points of $\mathrm{Na}_{2} \mathrm{O}-\mathrm{Al}_{2} \mathrm{O}_{3}-\mathrm{SiO}_{2}$ compounds lead to better behavior of mullite in molten salts, as compared to $\mathrm{SiO}_{2}-$ protected ceramics such as $\mathrm{SiC}$. Mullite-coated $\mathrm{SiC}$ is discussed, and the corrosion behavior is evaluated.

\section{Introduction}

$\mathrm{T}$ HE corrosive action of molten salts is a well-known problem for components in combustion environments.' Metallic alloys, as well as silicon-based ceramics, are susceptible to this type of corrosion. In the latter case, the process occurs by dissolution of the protective silica $\left(\mathrm{SiO}_{2}\right)$ scale to form a nonprotective liquid silicate: ${ }^{2}$

$$
2 \mathrm{SiO}_{2}(s)+\mathrm{Na}_{2} \mathrm{O}(s) \rightarrow \mathrm{Na}_{2} \mathrm{O} \cdot 2 \mathrm{SiO}_{2}(l)
$$

The introduction of alumina to the protective oxide scale leads to higher-melting $\mathrm{Na}_{2} \mathrm{O}-\mathrm{Al}_{2} \mathrm{O}_{3}-\mathrm{SiO}_{2}$ compounds ${ }^{3}$ and may provide significantly better corrosion resistance.

This consideration has led $\mathrm{us}^{4,5}$ and other investigators ${ }^{6,7}$ to consider mullite as a protective coating on silicon carbide ( $\mathrm{SiC}$ ). This coating system is attractive, because mullite has a coefficient of thermal expansion that is remarkably similar to that of $\mathrm{SiC}^{8}$ The purpose of this paper is to examine the interaction of mullite and mullite-coated $\mathrm{SiC}$ with $\mathrm{Na}_{2} \mathrm{O}$ at various chemical activities.

This system is best understood with the aid of the $\mathrm{Na}_{2} \mathrm{O}$ $\mathrm{Al}_{2} \mathrm{O}_{3}-\mathrm{SiO}_{2}$ phase diagram. An isothermal section at $1000^{\circ} \mathrm{C}^{3,9}$ is shown in Fig. 1. The major phases are silica, sodium silicates, mullite, corundum, nepheline $\left(\mathrm{Na}_{2} \mathrm{O} \cdot \mathrm{Al}_{2} \mathrm{O}_{3} \cdot 2 \mathrm{SiO}_{2}\right)$, and albite $\left(\mathrm{Na}_{2} \mathrm{O} \cdot \mathrm{Al}_{2} \mathrm{O}_{3} \cdot 6 \mathrm{SiO}_{2}\right)$. There also is a high-temperature form of nepheline-carnegieite. However, this should not form at the lower temperatures considered here. Also, many of these phases exist as solid solutions. Mullite and albite exist over a small solid-solution range, and nepheline exists over a larger range. These are shown as tick marks on the composition joins.

There is much information on the corrosion of refractory aluminosilicate compounds by sodium and potassium salts. These studies focus on such applications as glassmelting furnaces and coal gasifiers. Typically, these studies involve large amounts of $\mathrm{Na}_{2} \mathrm{O}$ and $\mathrm{K}_{2} \mathrm{O}$ at temperatures of $1000^{\circ}-1500^{\circ} \mathrm{C}$

M. Akine-contributing editor

\footnotetext{
Manuscript No. 192635. Received May 10, 1995; approved February 13, 1996.

Member, American Ceramic Society.

*Resident Research Associate from Cleveland State University, Cleveland, $\mathrm{OH}$ 44115 .
}

Farris and Allen ${ }^{10}$ have examined the corrosion of aluminosilicate refractories with soda $\left(\mathrm{Na}_{2} \mathrm{O}\right)$. A major issue was the fluidity of the molten salt and pore penetration, a well-known characteristic of molten salts. In general, the silica component reacts with soda first, and then the alumina component reacts. The major products are nepheline and a compound of composition $3 \mathrm{Na}_{2} \mathrm{O} \cdot 2 \mathrm{Al}_{2} \mathrm{O}_{3} \cdot 4 \mathrm{SiO}_{2}$. Sodium $\beta$-alumina $\left(11 \mathrm{Na}_{2} \mathrm{O} \cdot \mathrm{Al}_{2} \mathrm{O}_{3}\right)$ formed, but only at temperatures greater than $\sim 1100^{\circ} \mathrm{C}$.

Kennedy ${ }^{11}$ exposed mullite to soda at $1000^{\circ} \mathrm{C}$ for $125 \mathrm{~h}$ and found carnegieite and sodium $\beta$-alumina. He found the volume expansion associated with product formation was the major reason for degradation. Rigby and Hutton ${ }^{12}$ have examined corrosion of a series of alumina-silica compositions. For a $60: 40$ silica:alumina composition at $900^{\circ}$ and $1000^{\circ} \mathrm{C}$, sodium silicate formed first, followed by the reaction

$$
3 \mathrm{Al}_{2} \mathrm{O}_{3} \cdot 2 \mathrm{SiO}_{2}+\mathrm{Na}_{2} \mathrm{O} \rightleftarrows \mathrm{Na}_{2} \mathrm{O} \cdot \mathrm{Al}_{2} \mathrm{O}_{3} \cdot 2 \mathrm{SiO}_{2}+2 \mathrm{Al}_{2} \mathrm{O}_{3}
$$

For higher-alumina refractories, $\mathrm{NaAlO}_{2}$ also formed. At temperatures $\geq 1300^{\circ} \mathrm{C}$, sodium $\beta$-alumina will form.

Despite the different conditions of these investigations, there are some common observations. Albite has not been observed, although the phase diagram predicts that it is in equilibrium with mullite. 3,9 The phase diagram also indicates that nepheline should not be in equilibrium with mullite, yet these compounds frequently are observed together. Also, sodium $\beta$-alumina appears to form only at higher temperatures.

The focus of our research is on ceramics for heat-engine applications. In these cases, the corrodent exists as a thin film of $\mathrm{Na}_{2} \mathrm{SO}_{4}$ with a low activity of $\mathrm{Na}_{2} \mathrm{O}$. The refractory corrosion literature discussed above is for larger amounts of $\mathrm{Na}_{2} \mathrm{O}$ and correspondingly higher chemical activities. Nonetheless, this literature does provide some general guidelines for a heat-enginedirected study.

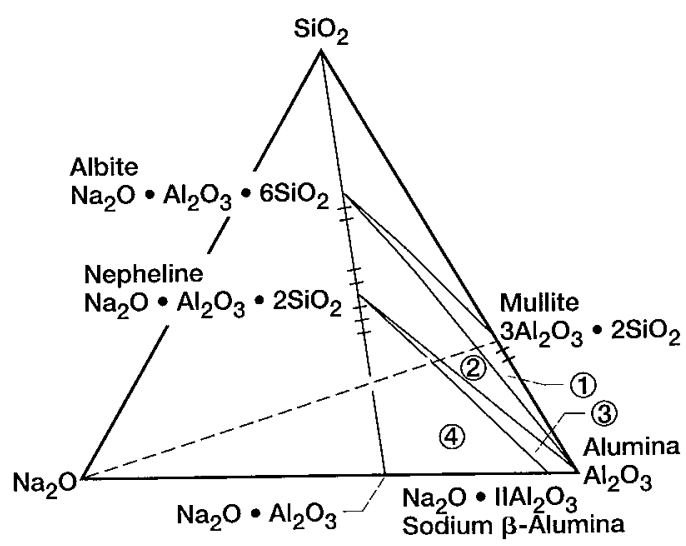

Fig. 1. Isothermal section for $T=1000^{\circ} \mathrm{C}$ of the $\mathrm{Na}_{2} \mathrm{O}-\mathrm{Al}_{2} \mathrm{O}_{3}-\mathrm{SiO}_{2}$ ternary. ${ }^{3,9}$ Crosshatched areas indicate solid-solution ranges. 


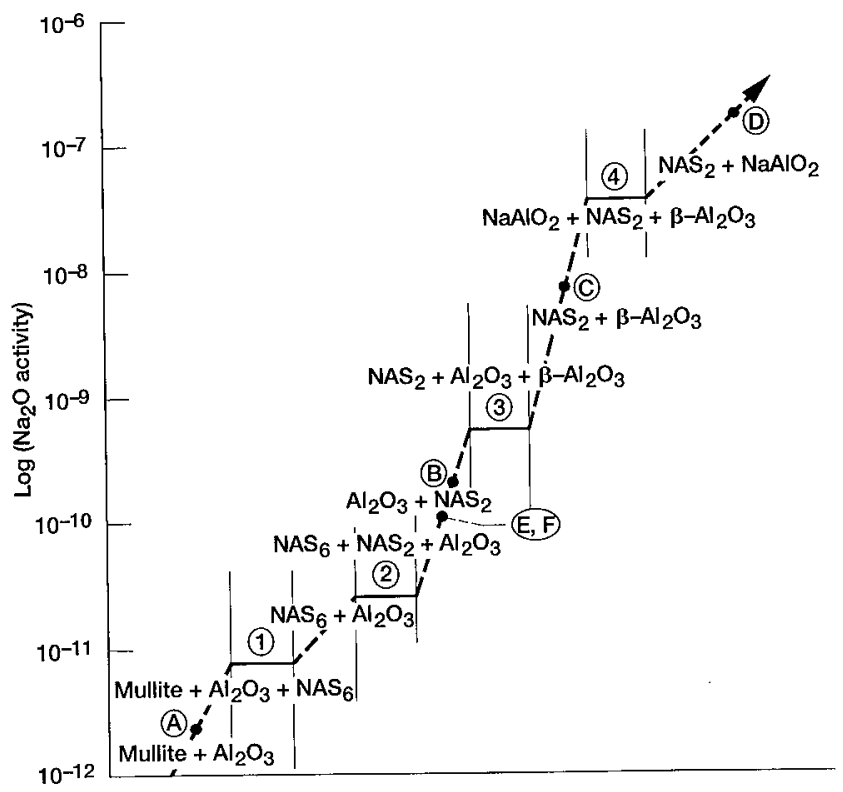

Fig. 2. Activity of $\mathrm{Na}_{2} \mathrm{O}$ along dashed line in Fig. 1 at $1000^{\circ} \mathrm{C}$. Abbreviations are $\mathrm{N}, \mathrm{Na}_{2} \mathrm{O} ; \mathrm{A}, \mathrm{Al}_{2} \mathrm{O}_{3}$; and $\mathrm{S}, \mathrm{SiO}_{2}$. Circled numbers refer to the compatibility triangles in Fig. 1; circled letters refer to the experimental conditions in Table II.

Here, the reactions of mullite and mullite-coated $\mathrm{SiC}$ with controlled activities of $\mathrm{Na}_{2} \mathrm{O}$ in both laboratory and jet-fuel burner experiments are examined. The mechanism of these reactions will be discussed in terms of the $\mathrm{Na}_{2} \mathrm{O}-\mathrm{Al}_{2} \mathrm{O}_{3}-\mathrm{SiO}_{2}$ ternary phase diagram.

\section{Thermodynamic Considerations}

The critical issue in these experiments is the thermodynamic activity of $\mathrm{Na}_{2} \mathrm{O}, a_{\mathrm{Na}_{2} \mathrm{O}}{ }^{2} \mathrm{~A}$ high activity of $\mathrm{Na}_{2} \mathrm{O}$ is termed a basic molten salt, and a low activity of $\mathrm{Na}_{2} \mathrm{O}$ is termed an acidic molten salt. This $\mathrm{Na}_{2} \mathrm{O}$ activity can be set by using thin films of $\mathrm{Na}_{2} \mathrm{CO}_{3}$ and $\mathrm{Na}_{2} \mathrm{SO}_{4}$ and an overpressure of $\mathrm{CO}_{2}(g)$ or $\mathrm{SO}_{3}(g)$, respectively:
Table I. Composition of Bulk Mullite

\begin{tabular}{lc}
\hline \multicolumn{1}{c}{ Element } & Amount (wt\%) \\
\hline Aluminum & 30.6 \\
Calcium & 0.03 \\
Copper & 0.01 \\
Iron & 0.3 \\
Sodium & 0.06 \\
Oxygen & bal. \\
Lead & 0.8 \\
Silicon & 15.9 \\
Titanium & 0.07 \\
Yttrium & 0.03 \\
Zinc & 0.01 \\
Zirconium & 0.4 \\
\hline
\end{tabular}

$$
\begin{aligned}
\mathrm{Na}_{2} \mathrm{CO}_{3}(l) & \leftrightarrows \mathrm{Na}_{2} \mathrm{O}(s, l)+\mathrm{CO}_{2}(g) \\
\left(a_{\mathrm{Na}_{2} \mathrm{O}}\right. & \left.=K_{3} / p_{\mathrm{CO}_{2}}=8.06 \times 10^{-7} / p_{\mathrm{CO}_{2}} \text { at } 1000^{\circ} \mathrm{C}\right) \\
\mathrm{Na}_{2} \mathrm{SO}_{4}(l) & \leftrightarrows \mathrm{Na}_{2} \mathrm{O}(s, l)+\mathrm{SO}_{3}(g) \\
\left(a_{\mathrm{Na}_{2} \mathrm{O}}\right. & \left.=K_{4} / p_{\mathrm{SO}_{3}}=4.06 \times 10^{-16} / p_{\mathrm{SO}_{3}} \text { at } 1000^{\circ} \mathrm{C}\right)
\end{aligned}
$$

$K_{3}$ and $K_{4}$ are the equilibrium constants for reactions (3) and (4), respectively, and have been calculated from the thermochemical tables. ${ }^{13}$ The chemical activity of $\mathrm{Na}_{2} \mathrm{CO}_{3}$ and $\mathrm{Na}_{2} \mathrm{SO}_{4}$ are taken as unity, because these are essentially pure phases. However, $\mathrm{Na}_{2} \mathrm{CO}_{3}$ still decomposes to a greater extent than $\mathrm{Na}_{2} \mathrm{SO}_{4}$ and forms a more basic salt.

The dashed line in Fig. 1 represents the addition of $\mathrm{Na}_{2} \mathrm{O}$ to mullite. Movement toward pure $\mathrm{Na}_{2} \mathrm{O}$ represents increasing the activity of $\mathrm{Na}_{2} \mathrm{O}$ through a series of compatibility triangles, labeled as $1,2,3$, and 4 in Fig. 1 . The $\mathrm{Na}_{2} \mathrm{O}$ activity in each triangle was determined from the following equilibria:

\begin{tabular}{|c|c|c|c|c|c|c|}
\hline \multirow[b]{2}{*}{ Condition* } & \multirow{2}{*}{$\begin{array}{c}\text { Description of } \\
\text { experimental condition }\end{array}$} & \multicolumn{2}{|c|}{ Calculated partial pressure (bar) } & \multirow{2}{*}{$\begin{array}{l}\text { Calculated activity of } \\
\mathrm{Na}_{2} \mathrm{O}, a_{\mathrm{Na}_{2} \mathrm{O}} \\
\end{array}$} & \multirow[b]{2}{*}{ Predicted phases } & \multirow[b]{2}{*}{ Observed phases } \\
\hline & & $p_{\mathrm{SO}_{2}}$ & $p_{\mathrm{SO}_{3}}$ & & & \\
\hline A & $\begin{array}{l}\text { Furnace; } \mathrm{Na}_{2} \mathrm{SO}_{4} / 930 \mathrm{ppmv} \\
\mathrm{SO}_{2}-\mathrm{O}_{2} \text { atmosphere, } \\
1000^{\circ} \mathrm{C}, 24 \mathrm{~h}\end{array}$ & $8.1 \times 10^{-4}$ & $1.2 \times 10^{-4}$ & $3.6 \times 10^{-12}$ & Mullite, $\mathrm{Al}_{2} \mathrm{O}_{3}, \mathrm{Na}_{2} \mathrm{SO}_{4}$ & $\begin{array}{l}\text { Mullite, } \mathrm{Na}_{2} \mathrm{SO}_{4} \text {, } \\
\qquad \mathrm{Al}_{2} \mathrm{O}_{3}\end{array}$ \\
\hline B & $\begin{array}{l}\text { Furnace; } \mathrm{Na}_{2} \mathrm{SO}_{4} / 11.56 \mathrm{ppmv} \\
\mathrm{SO}_{2}-\mathrm{O}_{2} \text { atmosphere, } 1000^{\circ} \mathrm{C} \\
24 \mathrm{~h}\end{array}$ & $1.0 \times 10^{-5}$ & $1.5 \times 10^{-6}$ & $2.7 \times 10^{-10}$ & $\begin{array}{l}\text { Mullite, } \mathrm{Al}_{2} \mathrm{O}_{3} \\
\mathrm{Na}_{2} \mathrm{O} \cdot \mathrm{Al}_{2} \mathrm{O}_{3} \cdot 6 \mathrm{SiO}_{2} \\
\mathrm{Na}_{2} \mathrm{O} \cdot \mathrm{Al}_{2} \mathrm{O}_{3} \cdot 2 \mathrm{SiO}_{2} \\
\mathrm{Na}_{2} \mathrm{SO}_{4}\end{array}$ & $\begin{array}{l}\text { Mullite, } \mathrm{Na}_{2} \mathrm{SO}_{4} \\
\mathrm{Al}_{2} \mathrm{O}_{3}, \\
\mathrm{Na}_{2} \mathrm{O} \cdot \mathrm{Al}_{2} \mathrm{O}_{3} \cdot 2 \mathrm{SiO}_{2}\end{array}$ \\
\hline $\mathrm{C}$ & $\begin{array}{l}\text { Furnace; } \mathrm{Na}_{2} \mathrm{SO}_{4} / 11.56 \mathrm{ppmv} \\
\mathrm{SO}_{2}-\mathrm{O}_{2} \text { atmosphere, } 1089^{\circ} \mathrm{C} \\
24 \mathrm{~h}\end{array}$ & $1.1 \times 10^{-5}$ & $8.7 \times 10^{-7}$ & $1.8 \times 10^{-8}$ & $\begin{array}{l}\text { Mullite, } \mathrm{Al}_{2} \mathrm{O}_{3} \\
\mathrm{Na}_{2} \mathrm{O} \cdot \mathrm{Al}_{2} \mathrm{O}_{3} \cdot 6 \mathrm{SiO}_{2} \\
\mathrm{Na}_{2} \mathrm{O} \cdot \mathrm{Al}_{2} \mathrm{O}_{3} \cdot 2 \mathrm{SiO}_{2} \\
\mathrm{Na} \beta-\mathrm{Al}_{2} \mathrm{O}_{3}, \mathrm{Na}_{2} \mathrm{SO}_{4}\end{array}$ & $\begin{array}{l}\text { Mullite, } \mathrm{Na}_{2} \mathrm{SO}_{4}, \\
\qquad \mathrm{Al}_{2} \mathrm{O}_{3}, \\
3 \mathrm{Na}_{2} \mathrm{O} \cdot 2 \mathrm{Al}_{2} \mathrm{O}_{3} \cdot 4 \mathrm{SiO}_{2}\end{array}$ \\
\hline $\mathrm{D}$ & $\begin{array}{r}\text { Furnace; } \mathrm{Na}_{2} \mathrm{CO}_{3} / 1 \mathrm{bar} \mathrm{CO}_{2} \\
\text { atmosphere, } 1000^{\circ} \mathrm{C}, 24 \mathrm{~h}\end{array}$ & & & $8.1 \times 10^{-7}$ & $\begin{array}{l}\text { Mullite, } \mathrm{Al}_{2} \mathrm{O}_{3} \\
\mathrm{Na}_{2} \mathrm{O} \cdot \mathrm{Al}_{2} \mathrm{O}_{3} \cdot 6 \mathrm{SiO}_{2} \\
\mathrm{Na}_{2} \mathrm{O} \cdot \mathrm{Al}_{2} \mathrm{O}_{3} \cdot 2 \mathrm{SiO}_{2} \\
\mathrm{Na} \mathrm{\beta}-\mathrm{Al}_{2} \mathrm{O}_{3} \\
\mathrm{Na}_{2} \mathrm{O} \cdot \mathrm{Al}_{2} \mathrm{O}_{3}\end{array}$ & $\begin{array}{l}\text { Mullite, } \\
\qquad \mathrm{Na}_{2} \mathrm{O} \cdot \mathrm{Al}_{2} \mathrm{O}_{3} \cdot \mathrm{SiO}_{2}\end{array}$ \\
\hline $\mathrm{E}$ & $\begin{array}{l}\text { Burner; } 2 \text { ppmw sodium, } 0.05 \% \\
\text { sulfur in fuel, fuel:air }= \\
0.025,1000^{\circ} \mathrm{C}, 4 \text { bar, } 40 \mathrm{~h}\end{array}$ & $2.7 \times 10^{-5}$ & $4.0 \times 10^{-6}$ & $1.0 \times 10^{-10}$ & $\begin{array}{l}\text { Mullite, } \mathrm{Al}_{2} \mathrm{O}_{3} \\
\mathrm{Na}_{2} \mathrm{O} \cdot \mathrm{Al}_{2} \mathrm{O}_{3} \cdot 6 \mathrm{SiO}_{2} \\
\mathrm{Na}_{2} \mathrm{O} \cdot \mathrm{Al}_{2} \mathrm{O}_{3} \cdot 2 \mathrm{SiO}_{2} \\
\mathrm{Na}_{2} \mathrm{SO}_{4}\end{array}$ & Mullite, $\mathrm{Na}_{2} \mathrm{SO}_{4}$ \\
\hline $\mathrm{F}$ & $\begin{array}{l}\text { Burner; } 2 \text { ppmw sodium, } 0.05 \% \\
\text { sulfur in fuel, fuel:air }= \\
0.025,1000^{\circ} \mathrm{C}, 4 \text { bar, } 40 \mathrm{~h}\end{array}$ & $2.7 \times 10^{-5}$ & $4.0 \times 10^{-6}$ & $1.0 \times 10^{-10}$ & $\begin{array}{l}\text { Mullite, } \mathrm{Al}_{2} \mathrm{O}_{3} \\
\mathrm{Na}_{2} \mathrm{O} \cdot \mathrm{Al}_{2} \mathrm{O}_{3} \cdot 6 \mathrm{SiO}_{2} \\
\mathrm{Na}_{2} \mathrm{O} \cdot \mathrm{Al}_{2} \mathrm{O}_{3} \cdot 2 \mathrm{SiO}_{2} \\
\mathrm{Na}_{2} \mathrm{SO}_{4}\end{array}$ & Mullite, $\mathrm{Na}_{2} \mathrm{SO}_{4}$ \\
\hline
\end{tabular}

$$
\begin{aligned}
& \mathrm{Na}_{2} \mathrm{O}+3\left(3 \mathrm{Al}_{2} \mathrm{O}_{3} \cdot 2 \mathrm{SiO}_{2}\right) \rightleftarrows \underset{\mathrm{Na}_{2} \mathrm{O} \cdot \mathrm{Al}_{2} \mathrm{O}_{3} \cdot 6 \mathrm{SiO}_{2}+8 \mathrm{Al}_{2} \mathrm{O}_{3}}{\rightleftarrows} \\
& \text { (Triangle 1: mullite/albite/alumina) } \\
& 2\left(\mathrm{Na}_{2} \mathrm{O} \cdot \mathrm{Al}_{2} \mathrm{O}_{3} \cdot 6 \mathrm{SiO}_{2}\right)+4 \mathrm{Na}_{2} \mathrm{O}+4 \mathrm{Al}_{2} \mathrm{O}_{3} \rightleftarrows \\
& 6\left(\mathrm{Na}_{2} \mathrm{O} \cdot \mathrm{Al}_{2} \mathrm{O}_{3} \cdot 2 \mathrm{SiO}_{2}\right)
\end{aligned}
$$

(Triangle 2: albite/nepheline/alumina)

Table II. Summary of Experimental Conditions, Phases Predicted from an Ideal Diffusion Path, and Phases Observed 


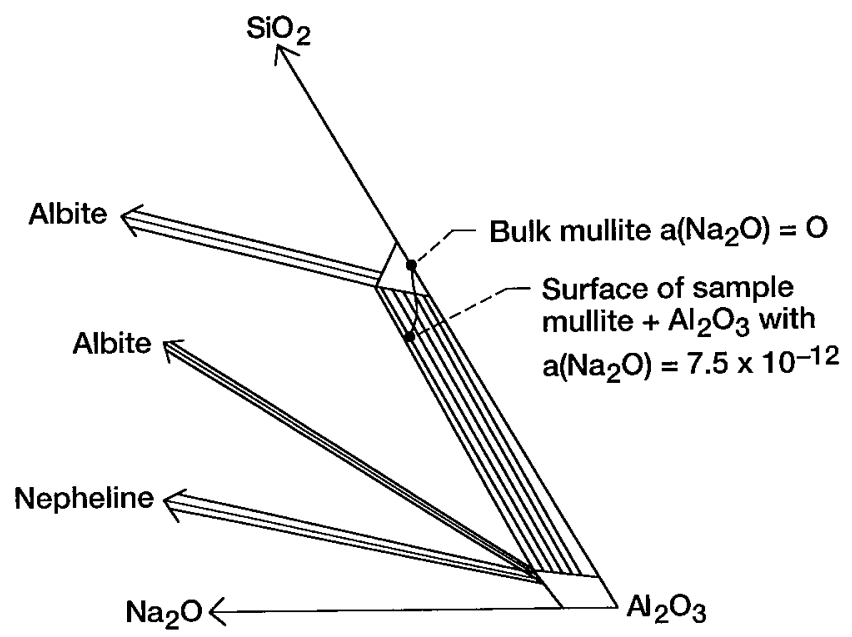

Fig. 3. Probable diffusion path for the reaction of mullite and $\mathrm{Na}_{2} \mathrm{O}$, with $a_{\mathrm{Na}_{2} \mathrm{O}}=3.6 \times 10^{-11}$ (condition A in Table II).

$$
\mathrm{Na}_{2} \mathrm{O}+11 \mathrm{Al}_{2} \mathrm{O}_{3} \rightleftarrows \mathrm{Na}_{2} \mathrm{O} \cdot 11 \mathrm{Al}_{2} \mathrm{O}_{3}
$$

(Triangle 3: nepheline/alumina/sodium $\beta$-alumina)

$$
10 \mathrm{Na}_{2} \mathrm{O}+\mathrm{Na}_{2} \mathrm{O} \cdot 11 \mathrm{Al}_{2} \mathrm{O}_{3} \rightleftarrows 11\left(\mathrm{Na}_{2} \mathrm{O} \cdot \mathrm{Al}_{2} \mathrm{O}_{3}\right)
$$

(Triangle 4: nepheline/sodium $\beta$-alumina/ $\mathrm{Na}_{2} \mathrm{O} \cdot \mathrm{Al}_{2} \mathrm{O}_{3}$ )

Only two phases are necessary to set the $\mathrm{Na}_{2} \mathrm{O}$ activity for triangles 3 and 4 . Thermodynamic data ${ }^{13,14}$ can be used to set up a plot of activity of $\mathrm{Na}_{2} \mathrm{O}$ versus composition from the above equilibria, as shown in Fig. 2 for $1000^{\circ} \mathrm{C}$. This analysis assumes stoichiometric compounds with no solid solubility, which is not the case for many of these, particularly $\mathrm{Na}_{2} \mathrm{O} \cdot \mathrm{Al}_{2} \mathrm{O}_{3} \cdot 2 \mathrm{SiO}_{2}$. These calculations do predict that for low $\mathrm{Na}_{2} \mathrm{O}$ activities, sodium aluminosilicates will form, and, for the higher $\mathrm{Na}_{2} \mathrm{O}$ activities, the compounds sodium $\beta$-alumina and sodium aluminate will form. This is consistent with the refractory corrosion literature that involves high $\mathrm{Na}_{2} \mathrm{O}$ activities and often produces sodium aluminates.

The heat-engine studies discussed here involve low activities of $\mathrm{Na}_{2} \mathrm{O}$. In our studies, the $\mathrm{Na}_{2} \mathrm{O}$ is not depleted, and we can regard this system as a diffusion couple of $\mathrm{Na}_{2} \mathrm{O}$ and mullite. There are many detailed studies of analogous metallurgical systems. ${ }^{15}$ The three oxides $-\mathrm{Na}_{2} \mathrm{O}, \mathrm{Al}_{2} \mathrm{O}_{3}$, and $\mathrm{SiO}_{2}$-are the three components of this system. If temperature, pressure, and composition are fixed, the phase rule then indicates that twophase regions are possible in the product layer between the $\mathrm{Na}_{2} \mathrm{O}$ and mullite. From the composition of these regions, delineation of some diffusion paths should be possible. Complications arise from the unknown identity of the diffusing species and extensive solid-solution formation in this system.

\section{Experimental Procedure}

The bulk mullite specimens were sintered from a powder made by a coprecipitation method (Tosoh Soda Co., Tokyo, Japan). A typical atomic emission analysis is shown in Table I. Coupons were cut to $\sim 2.0 \mathrm{~cm} \times 0.4 \mathrm{~cm} \times 0.3 \mathrm{~cm}$ and ground with $15 \mu \mathrm{m}$ diamond. One piece was polished further to a $1 \mu \mathrm{m}$ finish with diamond paste and examined with the scanning electron microscope (SEM). There was no evidence of a second phase.

In addition, some mullite-coated $\mathrm{SiC}$ was examined. Sintered $\alpha-\mathrm{SiC}$ with carbon and boron additives (Carborundum Co., Niagara Falls, NY) was used as the substrate of the same approximate dimension given above and coated on all six faces. The plasma-spray process used to deposit the mullite coating has been described in previous publications. ${ }^{4,5}$ It was shown that a thermal-shock-resistant coating can be applied by heating the substrate to ensure that the mullite retains its crystallinity.

Both the bulk and coated specimens were exposed to corrosive atmospheres in a laboratory furnace and a jet-fuel burner. These techniques have been described elsewhere. ${ }^{2}$ Briefly, heated coupons were air-brushed with an aqueous solution of $\mathrm{Na}_{2} \mathrm{SO}_{4}$ or $\mathrm{Na}_{2} \mathrm{CO}_{3}$. After the solution dried on the coupons, a film of salt remained. Dry salt loadings of $2-3 \mathrm{mg} / \mathrm{cm}^{2}$ were used for all coupons. Two to four coupons were examined for each condition. The coupons then were placed in a laboratory furnace with a fixed gas atmosphere at $1000^{\circ}$ or $1089^{\circ} \mathrm{C}$, which set the activity of $\mathrm{Na}_{2} \mathrm{O}$ as shown in reactions (3) and (4) above. A free-energy minimization computer code ${ }^{16}$ was used to calculate the values of equilibrium $p_{\mathrm{SO}_{2}}, p_{\mathrm{SO}_{3}}$, and $a_{\mathrm{Na}_{2} \mathrm{O}}$ for our furnace exposures; the inputs were the salt and gas atmosphere. The experimental conditions are summarized in Table II.
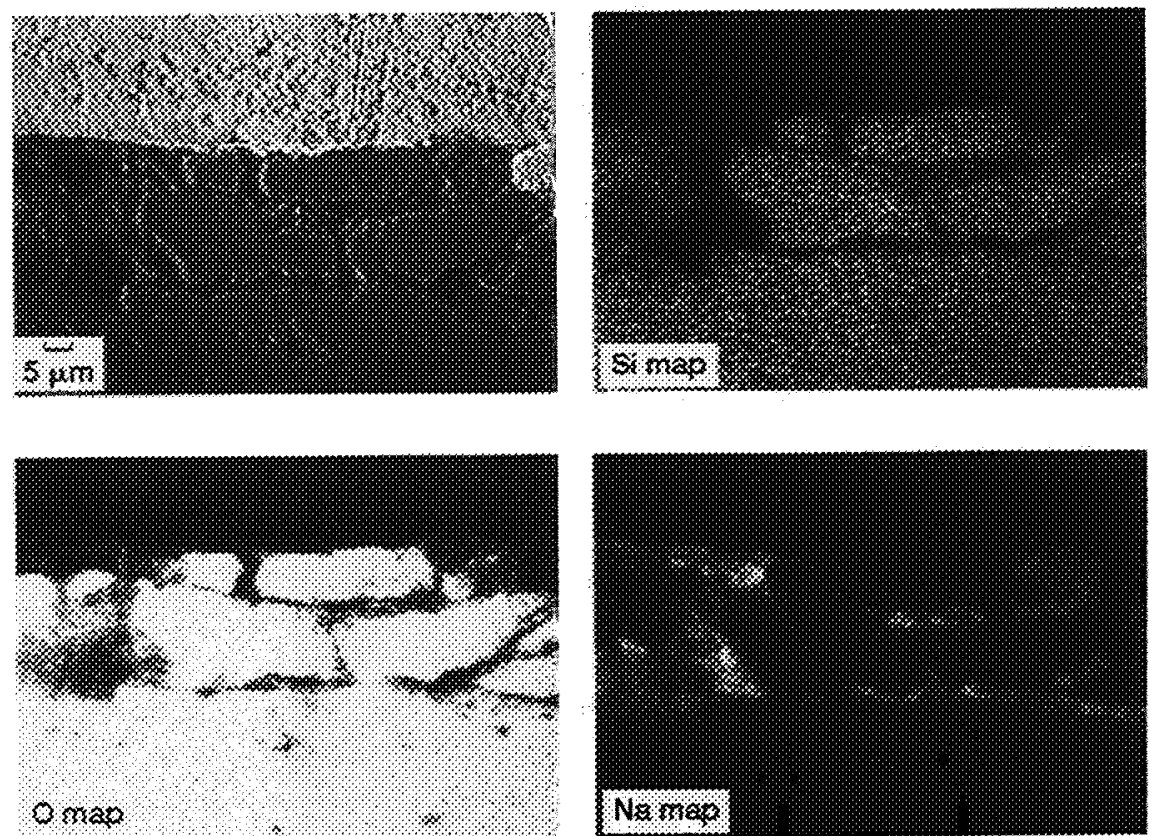
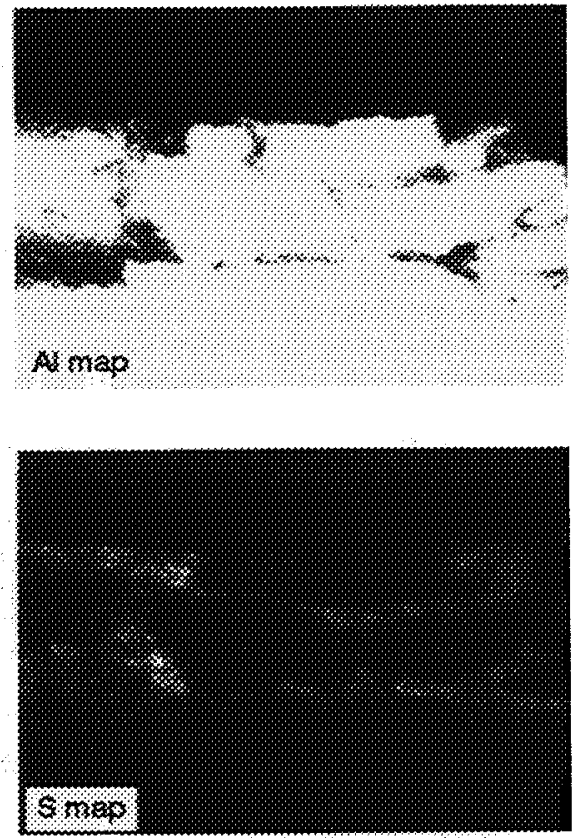

Fig. 4. Polished cross section and associated elemental dot maps for the reaction of mullite and $\mathrm{Na}_{2} \mathrm{O}$, with $a_{\mathrm{Na}_{2} \mathrm{O}}=2.9 \times 10^{-10}$ (condition B in Table II). 

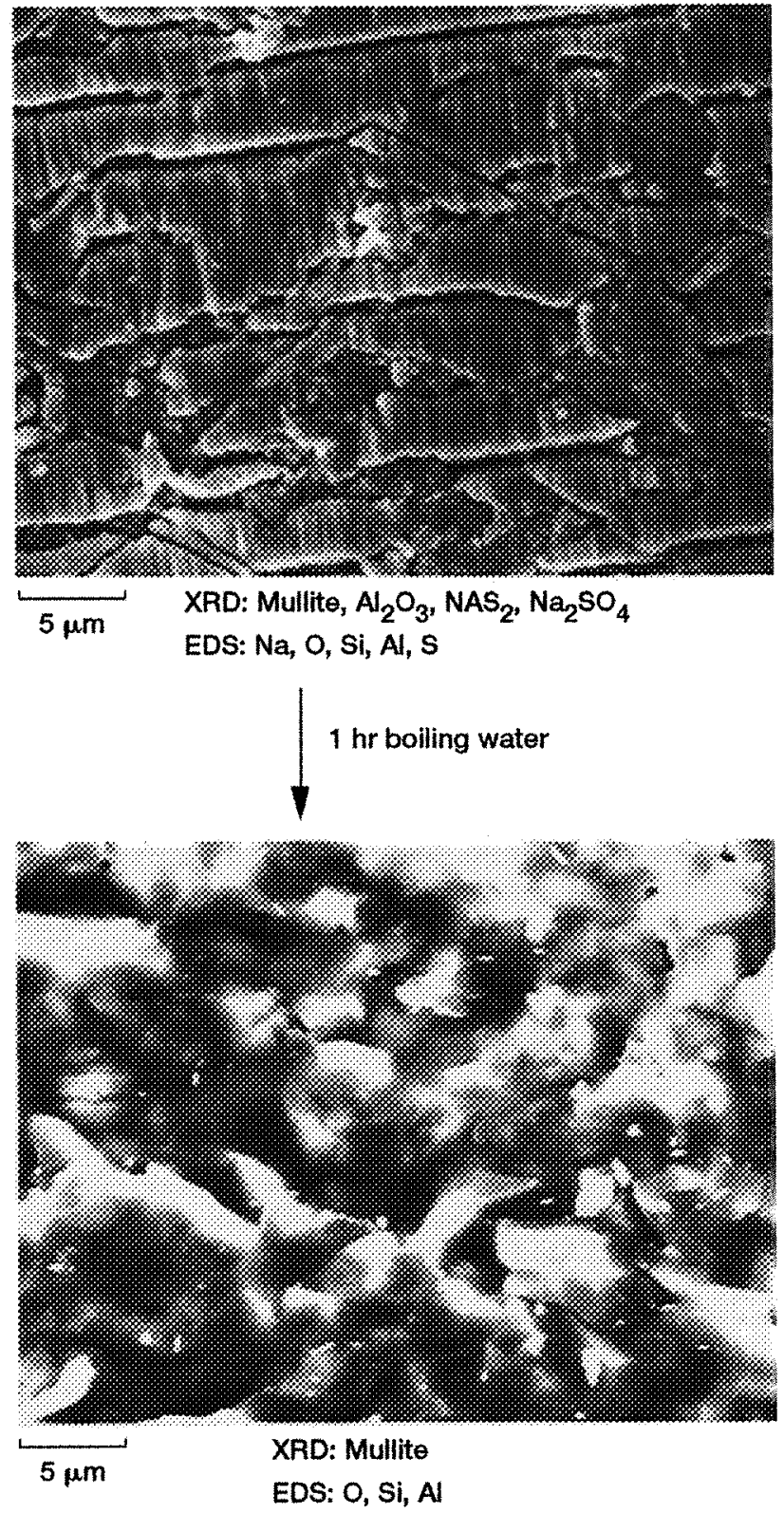

Fig. 5. Sequential removal of product layers for the reaction of mullite and $\mathrm{Na}_{2} \mathrm{O}$, with $a_{\mathrm{Na}_{2} \mathrm{O}}=2.9 \times 10^{-10}$ (condition B in Table II).

The burner conditions also have been described previously. ${ }^{17}$ These consist of a $4 \mathrm{~atm}(\sim 0.4 \mathrm{MPa})$ pressurized burner using Jet A fuel. Salt was added as $\mathrm{NaCl}$, which reacts with sulfur impurities in the fuel to form a $\mathrm{Na}_{2} \mathrm{SO}_{4}$ deposit. ${ }^{18}$ This type of situation simulates the actual corrosion process that occurs in a heat engine. Using the NASA Chemical Equilibrium Code, ${ }^{19}$ estimation of the $p_{\mathrm{SO}_{3}}$ generated in such a burner (2 ppm sodium, $0.05 \%$ sulfur, Jet A fuel) and then calculation of the activity of $\mathrm{Na}_{2} \mathrm{O}$ was possible. This information is given in Table II.

After exposure to these environments, the specimens were cooled and analyzed via several techniques. X-ray diffraction (XRD) was used to identify the crystalline phases. Even though there are many $\mathrm{Na}_{2} \mathrm{O}-\mathrm{SiO}_{2}-\mathrm{Al}_{2} \mathrm{O}_{3}$ compounds in the XRD card files, there was not always a clear match of our XRD scans to those on file. In addition, glasses may form from some of these compounds and would not be identifiable by XRD. Elemental analysis was helpful in these cases. Polished cross sections were prepared by sputter-coating samples with gold and then electroplating with a few millimeters of nickel or copper. Then, the sample was polished with diamond paste using ethylene glycol as a lubricant to preserve the water-soluble phases. The

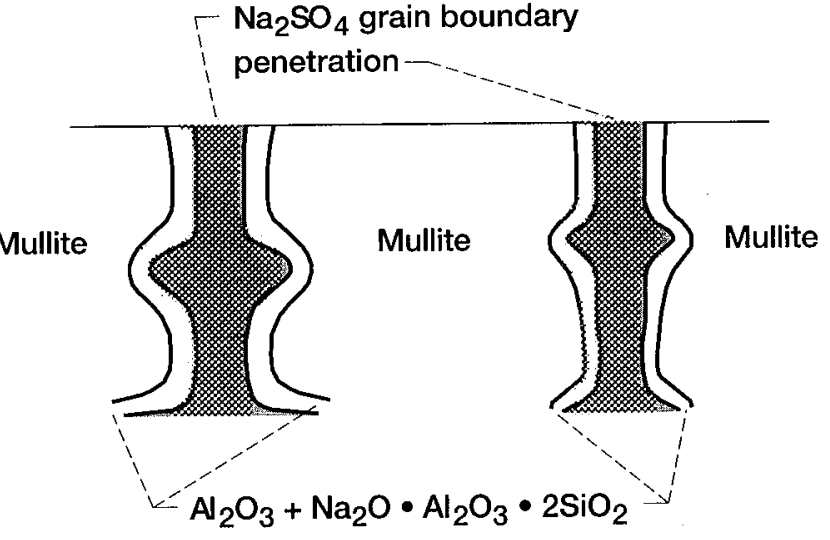

Fig. 6. Inferred cross-sectional structure of sample shown in Fig. 4.

thick conductive coating allowed electron optic examination and analysis through the entire thickness of the corrosion product. The sections were examined with an SEM equipped for energy-dispersive spectroscopy (EDS) and electron probe microanalysis (EPMA). For the EPMA measurements, the aluminum standard was $\mathrm{Al}_{2} \mathrm{O}_{3}$, the silicon standard was $\mathrm{SiO}_{2}$, the sodium standard was $\mathrm{NaF}$, and the oxygen standard was $\mathrm{MgO}$.

\section{Results and Discussion}

\section{(1) Furnace Studies}

Table II lists the predicted phases and observed products. Each of these experiments will be discussed, beginning with the most-acidic salt.

Condition $\mathrm{A}$ is the most-acidic salt, with $a_{\mathrm{Na}_{2} \mathrm{O}}=3.6 \times 10^{-12}$. XRD results indicated the presence of mullite, $\mathrm{Na}_{2} \mathrm{SO}_{4}$, and a small amount of $\mathrm{Al}_{2} \mathrm{O}_{3}$. A surface examination of the specimen in conjunction with EDS indicated an outer layer of condensed liquid $\mathrm{Na}_{2} \mathrm{SO}_{4}$, which is an effective source of $\mathrm{Na}_{2} \mathrm{O}$. The $\mathrm{Na}_{2} \mathrm{SO}_{4}$ was removed by dissolution in boiling water, revealing a rough surface with some degree of etching. XRD of this surface indicated only mullite. Apparently, the water-soluble layer contained $\mathrm{Na}_{2} \mathrm{SO}_{4}$ and $\mathrm{Al}_{2} \mathrm{O}_{3}$ (very likely as small particles).

From Fig. 2, the first three-phase region-mullite/alumina/ albite-occurs when $a_{\mathrm{Na}_{2} \mathrm{O}}=7.5 \times 10^{-12}$. The experimental conditions are less than this, so that only mullite and alumina are expected, as shown in Table II. These two phases have been observed experimentally. A proposed diffusion path is shown in Fig. 3, with the two-phase region between mullite and alumina enlarged to some solubility of $\mathrm{Na}_{2} \mathrm{O}$.

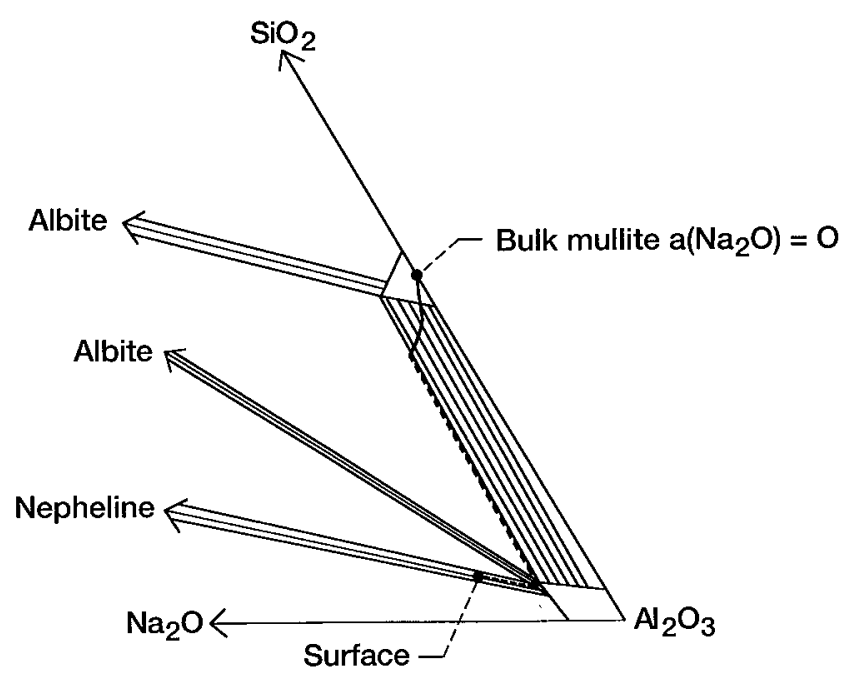

Fig. 7. Probable diffusion path for reaction examined in Fig. 4. 
(a)

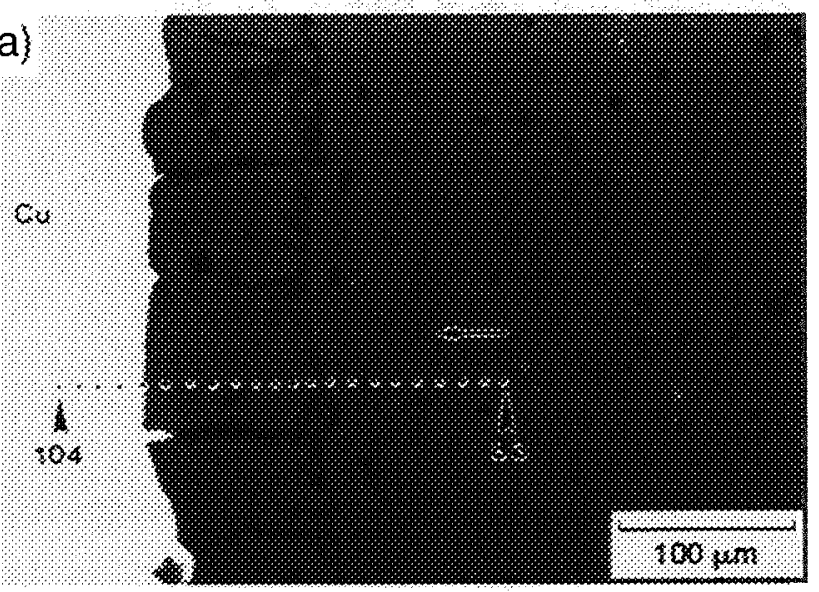

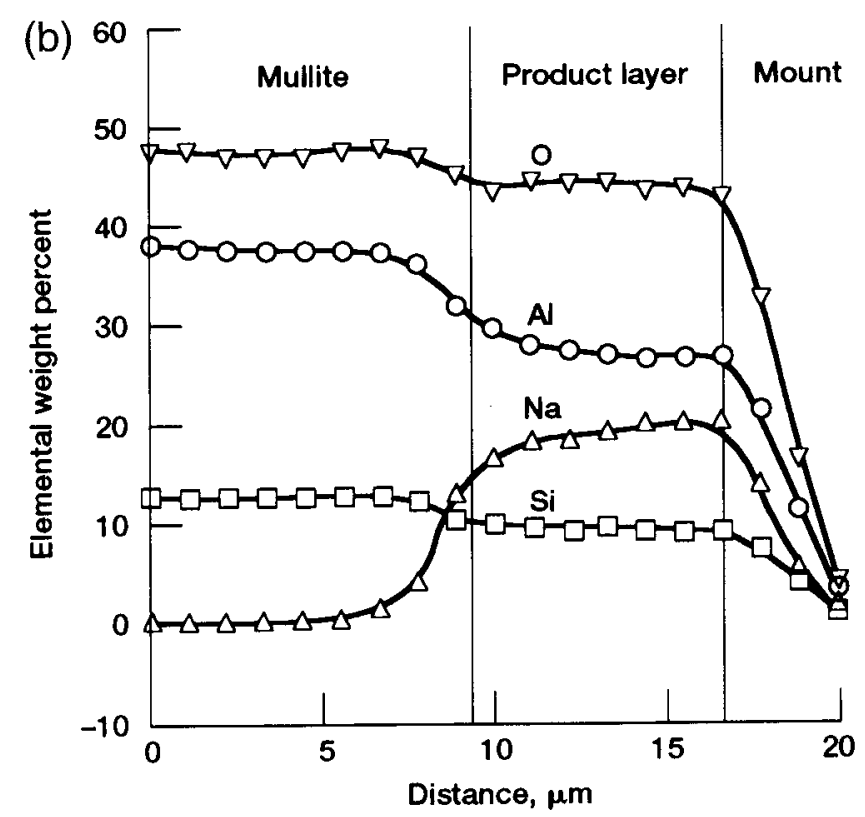

Fig. 8. EPMA of mullite reacted with $\mathrm{Na}_{2} \mathrm{CO}_{3}$ in 1.0 bar $\left(10^{5} \mathrm{~Pa}\right) \mathrm{CO}_{2}$ for $24 \mathrm{~h}$ at $1000^{\circ} \mathrm{C}$ (condition D in Table II) ((a) polished cross section and (b) quantitative elemental concentration profile).

Decreasing the amount of $\mathrm{SO}_{2}$ to $11.56 \mathrm{ppm}$ at $1000^{\circ} \mathrm{C}$ decreased the amount of $\mathrm{SO}_{3}$ and then, according to Eq. (4), increased $a_{\mathrm{Na}_{2} \mathrm{O}}$. This is condition $\mathrm{B}$ in Table II, with $a_{\mathrm{Na}_{2} \mathrm{O}}=$ $2.9 \times 10^{-10}$. In this case, XRD showed mullite, $\mathrm{Al}_{2} \mathrm{O}_{3}, \mathrm{Na}_{2} \mathrm{SO}_{4}$, and a very small amount of $\mathrm{Na}_{2} \mathrm{O} \cdot \mathrm{Al}_{2} \mathrm{O}_{3} \cdot 2 \mathrm{SiO}_{2}$. No $\mathrm{Na}_{2} \mathrm{O}$. $\mathrm{Al}_{2} \mathrm{O}_{3} \cdot 6 \mathrm{SiO}_{2}$ was detected. A polished cross section and associated X-ray dot maps are shown in Fig. 4. The corrosion-affected zone did not form a continuous product layer but rather a number of discontinuous regions $10-25 \mu \mathrm{m}$ thick, with the corrosion-affected zone separated from the bulk by the predominately $\mathrm{Na}_{2} \mathrm{SO}_{4}$ melt. $\mathrm{Na}_{2} \mathrm{SO}_{4}$ may initially attack the grain boundaries of the mullite, and then the melt may surround the grains or collections of grains. The grain size of the mullite was several micrometers, which is consistent with intergranular attack in Fig. 4.
To reveal more information about these corrosion products, the surfaces were examined in the SEM before and after a boiling-water treatment. This is shown in Fig. 5. Before the boiling-water treatment, the surface primarily was solidified $\mathrm{Na}_{2} \mathrm{SO}_{4}$, as indicated by EDS analysis and XRD. After treatment in boiling water, the diffraction peaks for $\mathrm{Na}_{2} \mathrm{SO}_{4}, \mathrm{Al}_{2} \mathrm{O}_{3}$, and $\mathrm{Na}_{2} \mathrm{O} \cdot \mathrm{Al}_{2} \mathrm{O}_{3} \cdot 2 \mathrm{SiO}_{2}$ disappeared, leaving only mullite peaks. Apparently, the melt that surrounded the mullite grains in Fig. 4 contained $\mathrm{Na}_{2} \mathrm{SO}_{4}, \mathrm{Al}_{2} \mathrm{O}_{3}$, and $\mathrm{Na}_{2} \mathrm{O} \cdot \mathrm{Al}_{2} \mathrm{O}_{3}$. $2 \mathrm{SiO}_{2}$, which again was an effective source of $\mathrm{Na}_{2} \mathrm{O}$. The limits of resolution of our microprobe did not allow us to distinguish these products.

A proposed cross-sectional structure from the outer melt layer to the mullite is shown schematically in Fig. 6. Figure 7 shows a probable diffusion path; this is idealized, because the
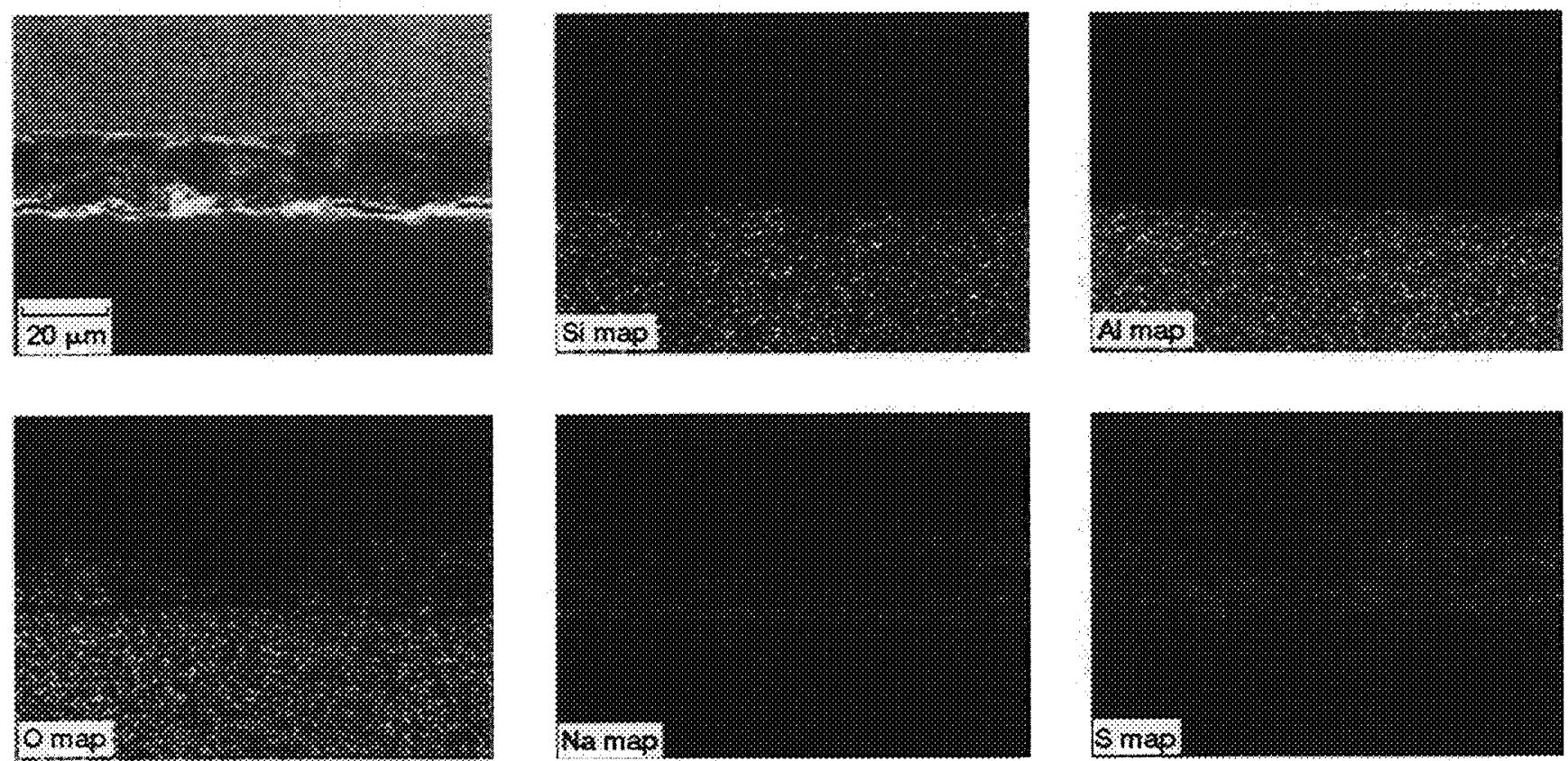

Fig. 9. Polished cross section and associated elemental maps for mullite reacted in the burner with a fuel-to-air ratio of 0.025 , Jet A fuel ( $0.05 \%$ sulfur), $2 \mathrm{ppm}$ sodium as $\mathrm{NaCl}$ for $40 \mathrm{~h}$ at $1000^{\circ} \mathrm{C}$, and $4 \mathrm{~atm}(\sim 0.4 \mathrm{MPa})$ (condition $\mathrm{E}$ in Table II). 

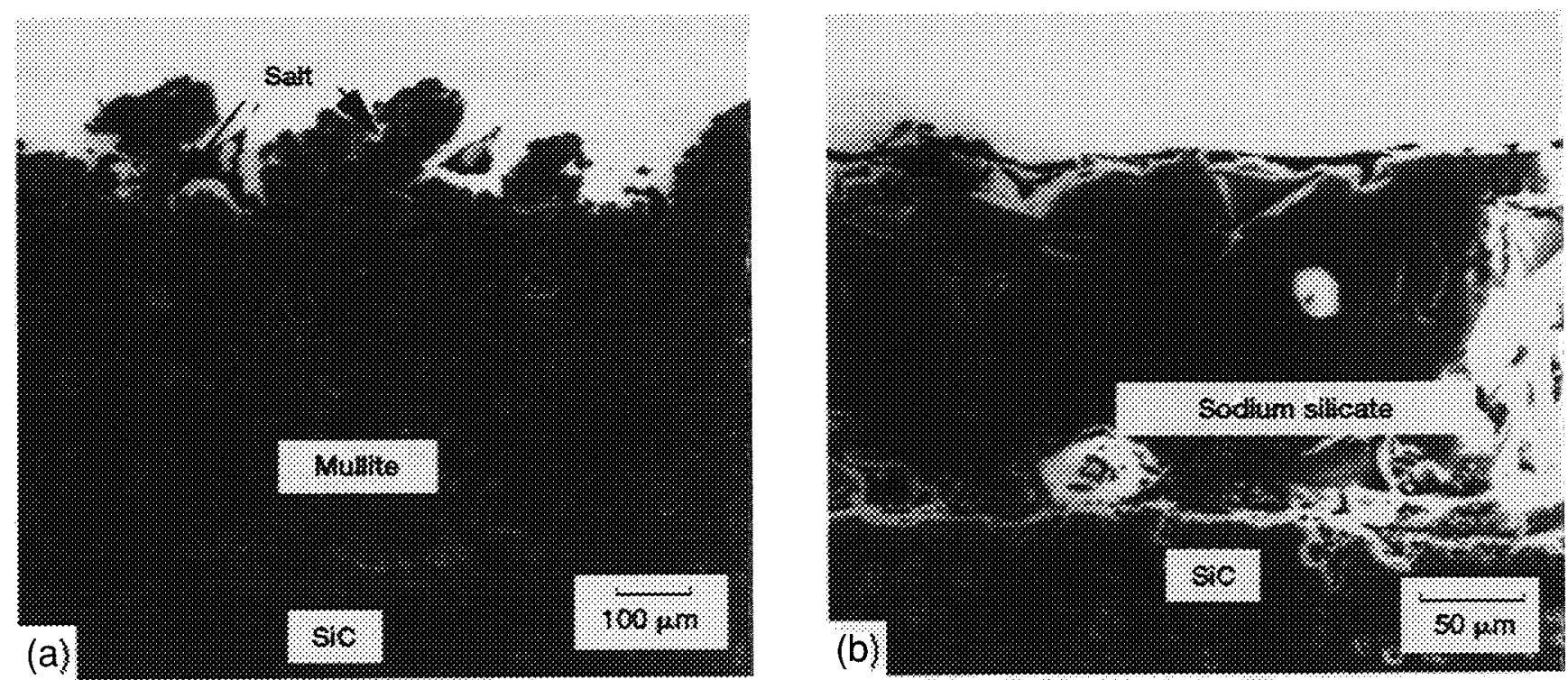

Fig. 10. Polished cross section after burner exposure; fuel-to-air ratio of 0.025 , Jet $\mathrm{A}$ fuel, $2 \mathrm{ppm}$ sodium as $\mathrm{NaCl}, 40 \mathrm{~h}$ at $1000^{\circ} \mathrm{C}$, and 4 bar (condition $\mathrm{F}$ in Table II) ((a) uncoated $\mathrm{SiC}$ and (b) $\mathrm{SiC}$ with mullite coating).

routes are shown along joins. Inititially, some of the $\mathrm{SiO}_{2}$ from the mullite is attacked by $\mathrm{Na}_{2} \mathrm{O}$, leaving $\mathrm{Al}_{2} \mathrm{O}_{3}$. The initial removal of $\mathrm{SiO}_{2}$ is consistent with the refractory corrosion studies of Rigby and Hutton, ${ }^{12}$ and Fig. 3 shows it as the diffusion path from the mullite to the pure $\mathrm{Al}_{2} \mathrm{O}_{3}$. By moving down to this region, the diffusion path can bypass the mullite/ alumina/albite and alumina/albite/nepheline compatibility triangles and move directly to the alumina/nepheline two-phase region. Some kinetic barrier to forming albite seems to exist, which is consistent with the refractory corrosion literature, as discussed in the Introduction. The primary product between the mullite and $\mathrm{Na}_{2} \mathrm{O}$ then is a two-phase mixture of $\mathrm{Al}_{2} \mathrm{O}_{3}$ and $\mathrm{Na}_{2} \mathrm{O} \cdot \mathrm{Al}_{2} \mathrm{O}_{3} \cdot 2 \mathrm{SiO}_{2}$

For condition $\mathrm{C}$ in Table II, the activity of $\mathrm{Na}_{2} \mathrm{O}$ was altered by increasing the temperature to $1089^{\circ} \mathrm{C}$ and keeping the amount of $\mathrm{SO}_{2}$ at $11.56 \mathrm{ppm}$, which leads to an $a_{\mathrm{Na}_{2} \mathrm{O}}$ value of $1.3 \times 10^{-8}$. XRD now showed $\mathrm{Na}_{2} \mathrm{SO}_{4}$, mullite, oriented $\mathrm{Al}_{2} \mathrm{O}_{3}$, and $3 \mathrm{Na}_{2} \mathrm{O} \cdot 2 \mathrm{Al}_{2} \mathrm{O}_{3} \cdot 4 \mathrm{SiO}_{2}$, which is analogous to the situation described above, but with a slightly different sodium aluminosilicate composition.

Condition D in Table II is a more-basic molten salt $-\mathrm{Na}_{2} \mathrm{CO}_{3}$ in 1 atm $\mathrm{CO}_{2}$. After only $\sim 5 \mathrm{~min}$, the $\mathrm{Na}_{2} \mathrm{CO}_{3}$ layer was not detectable anymore. This indicated that $\mathrm{Na}_{2} \mathrm{O}$ completely reacted with the mullite, and instead of a diffusion-couple situation, a condensed phase reaction of $\mathrm{Na}_{2} \mathrm{O}$ and mullite existed. After $24 \mathrm{~h}$ of reaction, a product layer $\sim 15 \mu \mathrm{m}$ thick formed. A polished cross section and associated quantitative microprobe trace is shown in Fig. 8. The estimated error in the elemental analysis was $\pm 1.5 \%$, primarily because of the porosity of the mullite. Converting the data to moles of the individual components form indicated that the product layer was $1.2 \mathrm{Na}_{2} \mathrm{O}$. $1.5 \mathrm{Al}_{2} \mathrm{O}_{3} \cdot 1 \mathrm{SiO}_{2}$. XRD showed the best match with the compound $\mathrm{Na}_{2} \mathrm{O} \cdot \mathrm{Al}_{2} \mathrm{O}_{3} \cdot \mathrm{SiO}_{2}$, in reasonable agreement with the EPMA data.

The layer of sodium aluminosilicate has uniform composition. When this layer reaches the mullite, there is a concentration decrease in the ratio of sodium to mullite. There may be some penetration of the mullite by sodium, which is expected because mullite can transport sodium cations. ${ }^{18,20}$

\section{(2) Burner Studies}

An actual corrosion situation is a hot flame seeded with salt that reacts with sulfur fuel impurities, leading to $\mathrm{Na}_{2} \mathrm{SO}_{4}$ deposits on the components. As discussed, this is best simulated

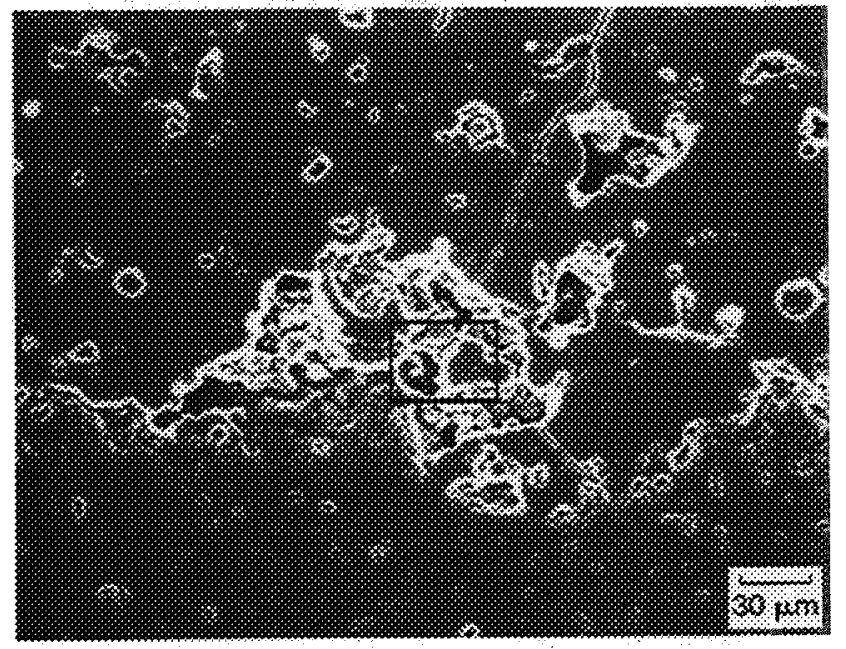

(a)

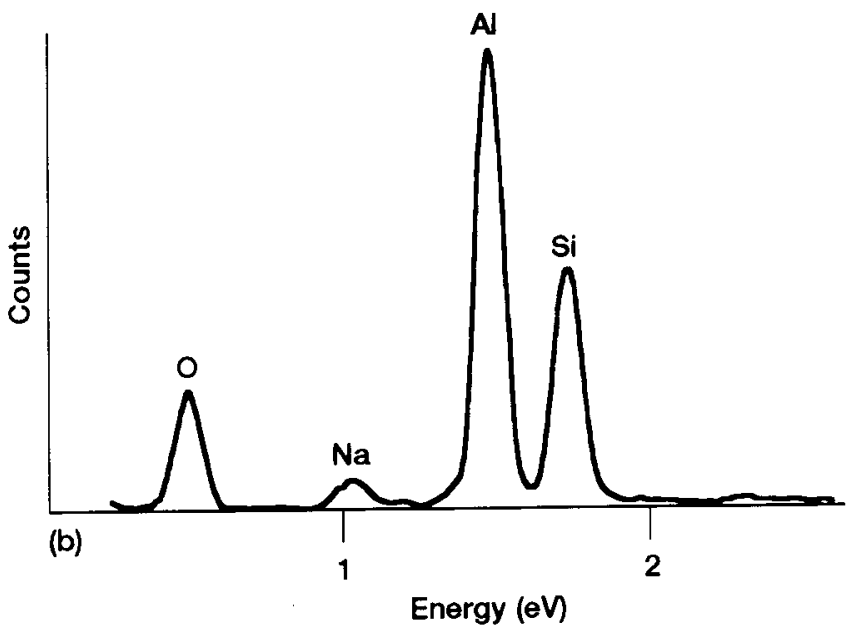

(b)

Fig. 11. SiC with mullite coating. Mullite/ $\mathrm{SiC}$ interface fuel-to-air ratio of 0.025 , Jet $\mathrm{A}$ fuel, $2 \mathrm{ppm}$ sodium as $\mathrm{NaCl}$, $40 \mathrm{~h}$ at $1000^{\circ} \mathrm{C}$, and $4 \mathrm{bar}$ (condition F in Table II) ((a) polished cross section and (b) EDS trace, showing presence of sodium). 
with a burner. Despite the complexity of a burner, determination of some basic chemical parameters and performance of an analysis similar to that conducted for the furnace are possible. As indicated in Table II, this produced an acidic salt deposit with $a_{\mathrm{Na}_{2} \mathrm{O}}=1.0 \times 10^{-10}$. Results were similar to the furnace tests with acidic salts.

A polished cross section is shown in Fig. 9, which clearly shows a layer of $\mathrm{Na}_{2} \mathrm{SO}_{4}$ on mullite, as indicated by the sulfur elemental dot map. There was no evidence of reaction, and, unlike the furnace situation, $\mathrm{Al}_{2} \mathrm{O}_{3}$ was not detected in XRD. $\mathrm{Al}_{2} \mathrm{O}_{3}$ may have formed only in very small quantities.

A polished cross section of mullite-coated $\mathrm{SiC}$ after burner treatment, test condition F in Table II, is shown in Fig. 10(a); this is compared to a coupon of uncoated $\mathrm{SiC}$ after a similar treatment, shown in Fig. 10(b). The mullite-coated SiC clearly shows substantially better behavior. The uncoated $\mathrm{SiC}$ forms a thick sodium silicate layer, whereas the mullite-coated material shows essentially no reaction. An examination of the mullite surface shows no evidence of reaction; only a small amount of $\mathrm{Na}_{2} \mathrm{SO}_{4}$ has deposited in the asperities.

There seems to be no reaction in this case. However, $\mathrm{Na}_{2} \mathrm{O}$ eventually will diffuse through the mullite and reach the mullite/SiC interface. Figure 11 shows the mullite/SiC interface and an associated EDS trace, which indicates the presence of sodium. As mentioned, mullite is well-known to be a good conductor for sodium. ${ }^{18,20}$ There are two driving forces for sodium diffusion through mullite: the activity gradient in sodium and sodium silicate formation. After long-term exposure, a liquid sodium silicate very likely will form at the mullite/SiC interface, which may lead to coating spallation. For long-term operation in sodium-containing atmospheres, a mullite coating is only a partial solution. Additional coating layers, which are better barriers to sodium, are necessary. ${ }^{21}$

\section{Summary and Conclusions}

The interaction of $\mathrm{Na}_{2} \mathrm{O}$ with mullite and mullite-coated $\mathrm{SiC}$ has been examined. Mullite generally behaves better in $\mathrm{Na}_{2} \mathrm{O}-$ containing environments than pure $\mathrm{SiO}_{2}$ because of the formation of higher-melting $\mathrm{Na}_{2} \mathrm{O}-\mathrm{Al}_{2} \mathrm{O}_{3}-\mathrm{SiO}_{2}$ compounds. The actual products are explained in terms of the thermodynamics of the system and diffusion paths in the $\mathrm{Na}_{2} \mathrm{O}-\mathrm{Al}_{2} \mathrm{O}_{3}-\mathrm{SiO}_{2}$ ternary. The more-aggressive burner tests are generally consistent with the furnace tests. The improved corrosion resistance of mullite and close coefficient of thermal expansion match to that of $\mathrm{SiC}$ make it a suitable protective-coating material. Over short terms, it looks quite promising. However, for longer times or in a high-sodium environment, the transport of sodium through mullite is a likely problem.

Acknowledgments: The authors would like to thank M. Cuy (NYMA, NASA Lewis Group) for the burner tests and J. Smith (NYMA, NASA Lewis Group) for the microprobe data. Helpful discussions with J. Nesbitt (NASA Lewis) also are appreciated.

\section{References}

${ }^{1}$ F. S. Pettit and C. S. Giggins, "Hot Corrosion"; pp. 327-54 in Superalloys II. Edited by C. T. Sims, N. S. Stoloff, and W. C. Hagel. Wiley, New York, 1987.

${ }^{2}$ N. S. Jacobson, J. L. Smialek, and D. S. Fox, "High-Temperature Corrosion of Engineering Ceramics"; pp. 514-47 in Corrosion of Glass, Ceramics, and Ceramic Superconductors. Edited by D. E. Clark and B. K. Zoitos. Noyes, Park Ridge, NJ, 1992

${ }^{3}$ E. M. Levin, C. R. Robbins, and H. F. McMurdie, Phase Diagrams for Ceramists; p. 181. American Ceramic Society, Columbus, OH, 1964.

${ }^{4}$ K. N. Lee, R. A. Miller, and N. S. Jacobson, "A New Generation of PlasmaSprayed Mullite Coatings on Silicon Carbide," J. Am. Ceram. Soc., 78 [3] 70510 (1995).

${ }^{5}$ K. N. Lee, R. A. Miller, and N. S. Jacobson, "Plasma-Sprayed Mullite Coatings on Silicon-Based Ceramics," U.S. Pat. No. 08/031,444, 1995.

'J. I. Federer, "Alumina Base Coatings for Protection of SiC Ceramics," J. Mater. Eng., 12 [2] 141-49 (1990).

JJ. R. Price, M. Van Roode, and C. Stala, "Ceramic Oxide-Coated Silicon Carbide for High-Temperature Corrosive Environments," Key Eng. Mater., 72-74, 71-84 (1992)

${ }^{8}$ Y. S. Touloukian, R. K. Kirby, R. E. Taylor, and T. Y. R. Lee, Thermal Expansion of Nonmetallic Solids. Plenum, New York, 1977.

${ }^{9} \mathrm{~J}$. J. Brown Jr. "The Use of Phase Diagrams to Predict Alkali Oxide Corrosion of Ceramics"; pp. 43-84 in Phase Diagrams in Advanced Ceramics. Edited by A. Alper. Academic Press, New York, 1994.

${ }^{10}$ R. E. Farris and J. E. Allen, "Aluminous Refractories-Alkali Reactions," Iron Steel Eng., 50 [2] 67-74 (1973).

${ }^{11}$ C. R. Kennedy, "Alkali Attack on a Mullite Refractory in the Grand Forks Energy Technology Center Slagging Gasifier," J. Mater. Energy Syst., 3, 2731 (1981).

${ }^{12}$ G. R. Rigby and R. Hutton, "Action of Alkali and Alkali-Vanadium Oxide Slags on Alumina-Silica Refractories," J. Am. Ceram. Soc., 45 [2] 68-73 (1962).

${ }^{13}$ I. Barin, Thermochemical Properties of Inorganic Substances, Parts I and II. VCH Verlagegesellschaft, Wieheim, Germany, 1989.

${ }^{14} \mathrm{~F}$. A. Elrefaire and W. W. Smeltzer "The Stability of $\mathrm{\beta}-\mathrm{Al}_{2} \mathrm{O}_{3}\left(\mathrm{Na}_{2} \mathrm{O} \cdot 11 \mathrm{Al}_{2} \mathrm{O}_{3}\right)$ in Oxygen Atmospheres," J. Electrochem. Soc., 128 [7] 1443-47 (1981).

${ }^{15} \mathrm{~F}$. J. J. van Loo, "Multiphase Diffusion in Binary and Ternary Solid-State Systems," Prog. Solid State Chem., 20, 47-99 (1990).

${ }^{16} \mathrm{HSC}$ Chemical Reaction and Equilibrium Software, Outokumpu Research, Pori, Finland, 1990

${ }^{17}$ N. S. Jacobson, C. A. Stearns, and J. L. Smialek, "Burner Corrosion of SiC at $1000^{\circ} \mathrm{C}$," Adv. Ceram. Mater., 1 [2] 154-61 (1986).

${ }^{18} \mathrm{~N}$. S. Jacobson, "Sodium Sulfate: Deposition and Dissolution of Silica," Oxid. Met., 31 [1/2] 91-103 (1989).

${ }^{19} \mathrm{~S}$. Gordon and B. J. McBride, "Computer Program for Calculation of Complex Chemical Equilibrium Compositions, Rocket Performance, Incident and Reflected Shocks, and Chapman-Jouguet Detonations," NASA Rept. No. SP-273, 1971.

${ }^{20} \mathrm{G}$. W. Watt, R. E. Andresen, and R. A. Rapp, "A Comparison of Reference Electrodes in Molten Sodium Sulfate"; p. 81 in Molten Salts. Edited by J. Braunstein and J. R. Selman. Electrochemical Society, Princeton, NJ, 1981.

${ }^{21} \mathrm{~K}$. N. Lee, N. S. Jacobson, and R. A. Miller, "Refractory Oxide Coatings on SiC Ceramics," MRS Bull., 19 [10] 35-38 (1994). 
